\title{
A comparative study of clinical profile \& investigative parameters of systemic lupus erythematosus patients with \& without metabolic syndrome
}

\author{
Rajadhyaksha A.G. ${ }^{1}$, Sarate N. ${ }^{2}$, Mangalgi S. ${ }^{3}$ \\ ${ }^{1}$ Dr. A.G. Rajadhyaksha, Professor, ${ }^{2}$ Dr. Nitin Sarate, Assistant Professor, ${ }^{3}$ Dr. Shreepriya Mangalgi, Resident Doctor, all \\ authors are affiliated with Department of Medicine, Seth G.S. Medical College \& KEM Hospital, Mumbai, Maharashtra, \\ India.
}

Corresponding Author: Dr. Nitin Sarate, Assistant Professor, Department of Medicine, Seth G.S. Medical College \& KEM Hospital, Mumbai, Maharashtra, India. E-mail: nitinsarate@gmail.com

\begin{abstract}
Introduction: The Metabolic Syndrome (MetS) often contributes to increased cardiovascular risk in patients with systemic lupus erythematosus (SLE) especially in younger age group. Determining the contribution of SLE phenotype and therapeutic exposures to the development of MetS in SLE patients would yield important insights into pathophysiology of cardiovascular events and help in Coronary Heart Disease (CHD) risk stratification. Objective: We aimed to get prevalence of metabolic syndrome in SLE patients \& to correlate its presence with demographic, socioeconomic, clinical manifestations, serological parameters, pharmacological treatment, disease activity, disease duration \& damage index. Method: A total 104 patients of SLE diagnosed as per American College of Rheumatology (ACR) criteria were enrolled during the study. Metabolic Syndrome was defined according to the American Heart Association \& National Heart, Lung \& Blood Institute modified National Cholesterol Education Programme Adult Treatment Panel III criteria (AHA/NHLBI modified NCEP/ATP III). Result: Out of 104 enrolled patients, MetS was present in 35 patients (33.7\%). Higher mean age (32.8 vs 27 years), Higher Body Mass Index (26.65 vs $\left.21.07 \mathrm{~kg} / \mathrm{m}^{2}\right)$, Increased triceps skin fold thickness $(20.46 \mathrm{vs} 15.80 \mathrm{~mm})$, longer disease duration (223.9wk vs $64.78 \mathrm{wk})$, the presence of lupus nephritis, hypertriglyceridemia, positive anti-ds DNA, higher serum creatinine, higher damage index \& higher cumulative dose of steroids were associated MetS in SLE patients. Conclusion: Screening for metabolic syndrome in patients with SLE will be helpful to minimize morbidity and mortality.
\end{abstract}

Key words: Systemic Lupus Erythematosus, Metabolic Syndrome, Atherosclerosis

\section{Introduction}

Systemic Lupus Erythematosus (SLE) is prototypic systemic autoimmune disease characterized by diverse multisystem involvement [1]. A bimodal mortality is observed in patients with SLE [2]. Early mortality is more likely to be related to disease itself, whereas late mortality is mainly associated with co-morbidities, coronary artery disease being one of the most common cause of morbidity and mortality at this stage [3-5].

Patients with SLE have a greater than fivefold increase risk of clinical coronary heart disease (CHD) events, rising to 50-fold increase in younger patient [6]. Subclinical atherosclerosis as measured by coronary

Manuscript received: $4^{\text {th }}$ December 2018

Reviewed: $10^{\text {th }}$ December 2018

Author Corrected: $15^{\text {th }}$ December 2018

Accepted for Publication: $19^{\text {th }}$ December 2018 calcium, carotid plaque, arterial stiffness and endothelial dysfunction is also increased in SLE patients [7-10]. Metabolic Syndrome (MetS) is characterized by a presence of hypertension, glucose intolerance, dyslipidemia \& obesity [11]. Data on the prevalence \& risk factors for MetS in SLE patients are scarce. Lupus features implicated in MetS include inflammatory disease activity, disease damage and therapeutic exposures, particularly corticosteroids, although studies to date have been inconsistent [12].

Determining the contribution of SLE phenotype and therapeutic exposures to the development of MetS in SLE patients would yield important insights into pathophysiology of cardiovascular events and help in CHD risk stratification. 


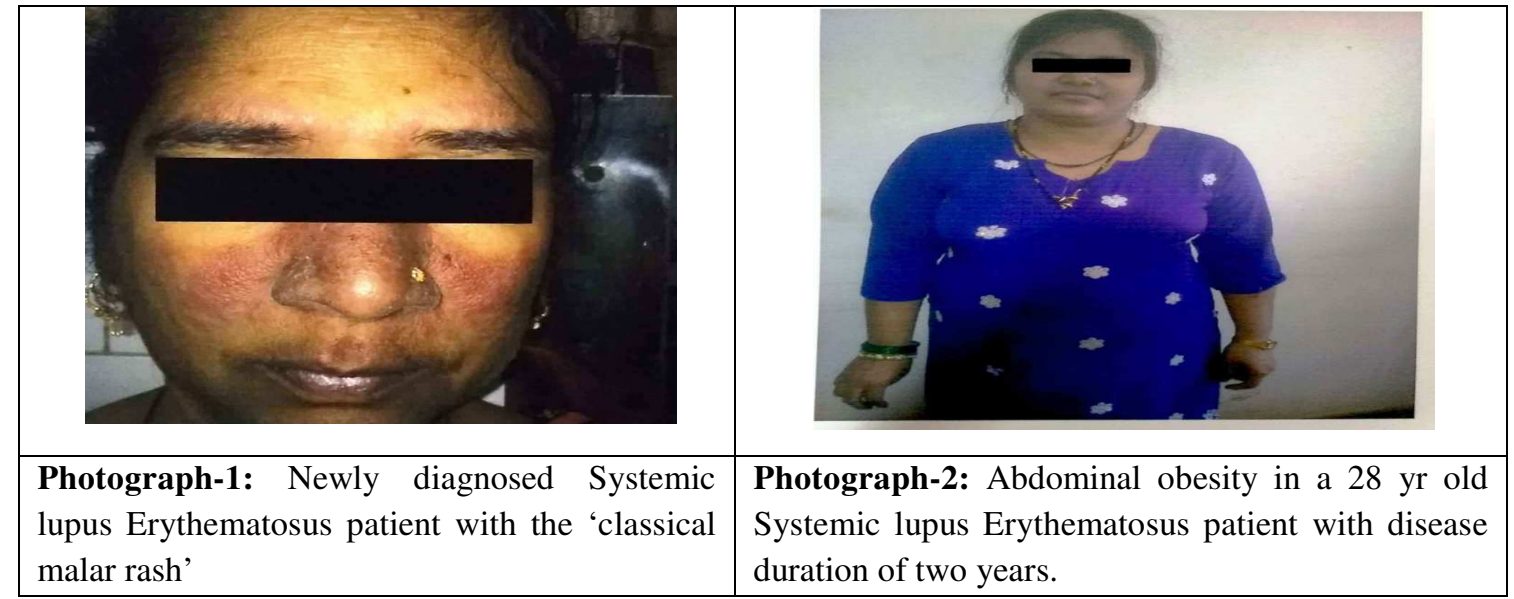

\section{Materials \& Method}

Objective: Main objective was to study prevalence of metabolic syndrome in diagnosed patient of SLE \& to co-relate presence of metabolic syndrome with demographic, socio-economic parameters, clinical manifestations, serological features, pharmacological treatment, disease activity, disease duration and damage index in patients of SLE.

Place \& Type of Study: This Cross Sectional \& Observational study was conducted in a tertiary care centre in Mumbai for period of 18 months after obtaining approval from the Institutional Ethics Committee.

Sampling Method: Considering the average prevalence of metabolic syndrome in patients with SLE to be around 33\% based on various studies, the sample size for our study was estimated to be 85 with confidence level $95 \%$ \& margin error of $10 \%$ [12-16]. A total 104 SLE patients utilizing rheumatology services of a tertiary care hospital were enrolled during the study.

\section{Inclusion Criteria}

a) Patient diagnosed to have SLE based on American College of Rheumatology Criteria ( ACR )

b) Age more than 12 year

c) Patient willing to give informed written consent for participation in study.

Exclusion Criteria: Patient who were pregnant at time of study visit.

Statistical Method: Descriptive statistics will be performed and indicated as mean \pm standard deviation and median for continuous variables. The two independent group comparisons will be performed by student $t$ test. ANNOVA will be used to evaluate correlation between continuous variables and Chi square test will be used to examine the differences between groups in terms of categorical variables. $P$ values less than 0.05 were considered significant.

Study Procedure: Once all the criteria were satisfied, a written informed consent was taken from all the patients or their relatives/guardian (In case of minors). Data regarding demographic \& socio-economic parameters (age, gender, literacy, occupation, religion \& marital status) were gathered. General \& Systemic Examination was performed. Body Mass Index (BMI), Waist circumference, tricep skin fold thickness were also measured. Disease manifestations, as defined in the ACR classification criteria for SLE were noted [17]. Systemic Lupus Disease Activity Index 2000 (SLEDAI-2K) Score was used for the measurement of the disease activity whereas damage index was assessed using Systemic Lupus Collaborating Clinic/ ACR Damage Index (SLICC/ACR-DI) [18,19]. Routine blood investigations like complete blood (CBC) counts, Erythrocyte Sedimentation Rate (ESR), Fasting \& Post-prandial blood glucose, lipid profile, serum uric acid, renal \& liver function tests, Urine- routine/microscopy \& $24 \mathrm{hr}$ urine protein test were performed. Additionally specific tests like ANA, Anti-dsDNA titres, $\mathrm{C}_{3} \& \mathrm{C}_{4}$ complement levels, CRP levels, Anticardiolipin antibody (ACLA) IgG \& IgM were done. Chest radiograph, electrocardiogram \& ultrasound studies (wherever indicated) were performed. Carotid ultrasound was performed with Philips En Visor Ultrasound System using high frequency linear duplex Doppler transducer of 7.5-10 MHz for the real time imaging. The scanning was performed at right \& left carotid territories. The common carotid artery (1 $\mathrm{cm}$ proximal to bifurcation) intima-media thickness (IMT) was measured. 
The AHA/NHLBI modified NCEP/ATP III was used to determine presence of metabolic syndrome at study visit [20]. Patients were diagnosed to have metabolic syndrome if three or more of the following criteria were present.

\section{Results}

Table No.-1: Characteristics of SLE Patients enrolled in the present Study.

\begin{tabular}{|c|c|c|c|c|c|c|c|}
\hline Sr. No. & \multicolumn{2}{|c|}{ Parameters studied } & \multicolumn{5}{|c|}{ Results } \\
\hline 1 & \multicolumn{2}{|c|}{ SLE with MetS (n \& \%) } & \multicolumn{5}{|c|}{$35(33.7 \%)$} \\
\hline 2 & \multicolumn{2}{|c|}{ Gender distribution [n \& \%] } & $\begin{array}{r}\text { Femal } \\
102(98.1\end{array}$ & & \multicolumn{2}{|c|}{$\begin{array}{c}\text { Male } \\
02(1.9 \%)\end{array}$} & $\begin{array}{l}\text { Total No of } \\
\text { patients } 104\end{array}$ \\
\hline 3 & \multicolumn{2}{|c|}{ Mean Age [years, (SD)] } & \multicolumn{3}{|c|}{ With MetS 32.86( \pm 9.340$)$} & \multicolumn{2}{|c|}{$\begin{array}{c}\text { Without MetS } \\
27.2( \pm 9.779)\end{array}$} \\
\hline 4 & \multicolumn{2}{|c|}{$\begin{array}{l}\text { Distribution of individual components of MetS } \\
\text { in study population } \\
\text { - Waist circumference }(\geq 102 \mathrm{~cm} \text { in men } \& \geq 88 \mathrm{~cm} \\
\text { in women) } \\
\text { - High triglycerides } \\
\text { - Low HDL-cholesterol } \\
\text { - Impaired fasting glucose } \\
\text { - Hypertension }\end{array}$} & \multicolumn{3}{|c|}{ 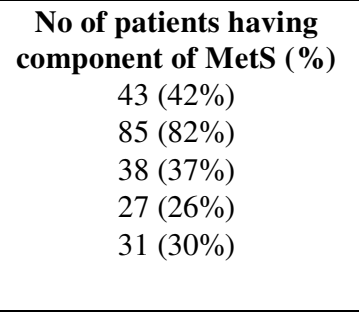 } & \multicolumn{2}{|c|}{$\begin{array}{c}\text { No of patients having } \\
\text { without component of } \\
\text { MetS (\%) } \\
61(58 \%) \\
19(18 \%) \\
66(63 \%) \\
77(74 \%) \\
73(70 \%)\end{array}$} \\
\hline $\begin{array}{l}5 \\
6 \\
7\end{array}$ & \multicolumn{2}{|c|}{$\begin{array}{l}\text { Mean BMI of SLE patients (SD) } \\
\text { Mean tricep skin thickness (mm)(SD) } \\
\text { Mean disease duration since the diagnosis } \\
\text { (weeks) (SD) }\end{array}$} & \multicolumn{3}{|c|}{$\begin{array}{c}\text { With MetS } \\
26.65( \pm 3.134) \\
20.46( \pm 3.534) \\
223.69( \pm 197.416) \\
\end{array}$} & \multicolumn{2}{|c|}{$\begin{array}{c}\text { Without MetS } \\
21.07( \pm 3.819) \\
15.80( \pm 3.261) \\
64.78( \pm 73.567) \\
\end{array}$} \\
\hline 8 & \multicolumn{2}{|c|}{$\begin{array}{l}\text { Lupus Nephritis Class } \\
\text { - Nil } \\
\text { - I } \\
\text { - II } \\
\text { - III } \\
\text { - IV } \\
\text { - V } \\
\text { - VI } \\
\text { - Total } \\
\end{array}$} & \multicolumn{3}{|c|}{$\begin{array}{c}\text { With MetS }(\%) \\
4(11.4) \\
0(0) \\
1(2.9) \\
5(14.3) \\
22(62.9) \\
1(2.9) \\
2(5.7) \\
35(100)\end{array}$} & \multicolumn{2}{|c|}{$\begin{array}{c}\text { Without MetS(\%) } \\
23(33.3) \\
0(0) \\
9(13.0) \\
4(5.8) \\
30(43.5) \\
2(2.9) \\
1(1.4) \\
69(100)\end{array}$} \\
\hline 9 & $\begin{array}{l}\text { Neuropsychiat } \\
\text { ric } \\
\text { involvement }\end{array}$ & $\begin{array}{l}\text { - yes } \\
\text { - no }\end{array}$ & \multicolumn{3}{|c|}{$\begin{array}{l}\text { With MetS (\%) } \\
7(20) \\
28(80)\end{array}$} & \multicolumn{2}{|c|}{$\begin{array}{c}\text { Without MetS (\%) } \\
8(11.6) \\
61(88.4)\end{array}$} \\
\hline 10 & 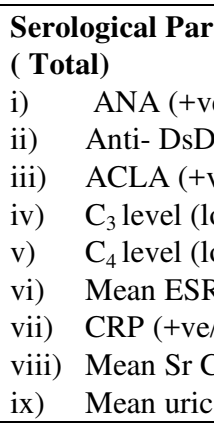 & $\begin{array}{l}\text { meters at Study Visit } \\
\text { (-ve) } \\
\text { JA (+ve/-ve) } \\
\text { /-ve) } \\
\text { w/normal) } \\
\text { w/normal) } \\
\text { (SD) } \\
\text { ve) } \\
\text { eatine (SD) } \\
\text { ccid level(SD) }\end{array}$ & $\begin{array}{r}\text { With } \\
\\
\\
42.1 \\
\\
1.0486 \\
5.67 \\
\end{array}$ & $\begin{array}{l}18 \\
25 \\
22 \\
26 \\
27 \\
\pm 2\end{array}$ & & $\begin{array}{r}52.2 \\
0.9217 \\
5.28 \\
\end{array}$ & $\begin{array}{l}\text { MetS (69) } \\
4 / 5 \\
7 / 42 \\
4 / 45 \\
5 / 34 \\
1 / 48 \\
( \pm 22.24) \\
2 / 27 \\
\pm 0.28536) \\
\pm 5.011) \\
\end{array}$ \\
\hline 11 & $\begin{array}{l}\text { Disease Activity } \\
\text { SLEDAI-2K Sce } \\
\text { SLICC/ACR-DI }\end{array}$ & $\begin{array}{l}\text { \& Damage Index } \\
\text { (SD) } \\
\text { SD) }\end{array}$ & $\begin{array}{r}\mathbf{W i} \\
3.42 \\
0.62\end{array}$ & & & $\begin{array}{r}\text { With } \\
5.33 \\
0.31\end{array}$ & $\begin{array}{l}\text { MetS } \\
( \pm 6.857) \\
( \pm 0.63)\end{array}$ \\
\hline 12 & $\begin{array}{l}\text { Treatment Par: } \\
\text { dose (gm)(SD) } \\
\text { i) Methylpredn } \\
\text { ii) Prednisolone } \\
\text { iii) Cyclophospl }\end{array}$ & $\begin{array}{l}\text { meters A]Mean Cumulative } \\
\text { solone (iv) } \\
\text { (oral) } \\
\text { mide (iv) }\end{array}$ & $\begin{array}{r}\mathbf{W i} \\
\\
3.44 \\
15.81 \\
11.5 \\
\end{array}$ & & & $\begin{array}{r}2.92 \\
6.24 \\
7.28\end{array}$ & $\begin{array}{l}\text { MetS } \\
\pm 0.335) \\
( \pm 4.067) \\
\pm 4.452) \\
\end{array}$ \\
\hline & $\begin{array}{l}\text { B] Usage of Im } \\
\text { i) Cyclophosph } \\
\text { ii) Mycophenol } \\
\text { iii) Azathioprine }\end{array}$ & $\begin{array}{l}\text { Iune-suppressive Therapy } \\
\text { mide } \\
\text { te mofetil }\end{array}$ & $\begin{array}{c}\begin{array}{c}\text { On } \\
\text { therapy }\end{array} \\
30 \\
2 \\
7\end{array}$ & & rapy & $\begin{array}{c}\text { On } \\
\text { therapy } \\
30 \\
10 \\
4\end{array}$ & \begin{tabular}{|c|}
$\begin{array}{c}\text { Not } \\
\text { therapy }\end{array}$ \\
39 \\
59 \\
65 \\
\end{tabular} \\
\hline 13 & $\begin{array}{l}\text { Mean Carotid } \\
(\mathrm{cm})(\mathrm{SD})\end{array}$ & rtery intima-media thickness & & & & & $\begin{array}{l}\text { ut MetS } \\
( \pm 0.005) \\
\end{array}$ \\
\hline
\end{tabular}


1. Arterial hypertension (Systolic $\mathrm{BP} \geq 130 \mathrm{~mm}$ of $\mathrm{Hg}$ or diastolic $\mathrm{BP} \geq 85 \mathrm{~mm}$ of $\mathrm{Hg}$ or drug treatment for hypertension)

2. Increased fasting glucose $(\geq 100 \mathrm{mg} / \mathrm{dL}$ or drug treatment for diabetes)

3. Reduced high-density lipoprotein( HDL) Cholesterol $(<40 \mathrm{mg} / \mathrm{dL}$ in men, $<50 \mathrm{mg} / \mathrm{dL}$ in women or drug treatment of low HDL cholesterol)

4. Increased triglycerides ( $\geq 150 \mathrm{mg} / \mathrm{dL}$ or drug treatment of hypertriglyceridemia)

5. Increased waist circumference ( $\geq 102 \mathrm{~cm}$ in men, $\geq 88 \mathrm{~cm}$ in women)

At the end of the study duration, the patient data was tabulated \& analysed. The prevalence of metabolic syndrome in SLE patients was determined. Differences between SLE patients with and without metabolic syndrome in terms of demographic and socio-economic parameters, clinical manifestations, serological features, pharmacological treatment, disease activity \& damage index were analysed using appropriate statistical methods.

Table-2: Significant factors associated with MetS at enrolment in present study.

\begin{tabular}{|c|c|c|c|c|}
\hline \multirow[t]{2}{*}{ Sr. No. } & \multirow[t]{2}{*}{ Parameter Studied } & \multicolumn{2}{|c|}{ Metabolic Syndrome (MetS) } & \multirow{2}{*}{$\begin{array}{c}\text { Analysis / } \\
\text { P value }\end{array}$} \\
\hline & & Yes ( SD) & No ( SD) & \\
\hline 1 & Mean age of the patient (Yr) & $32.86( \pm 9.34)$ & $27( \pm 9.779)$ & $\mathrm{P}=0.006$ \\
\hline 2 & Mean Body Mass Index & $26.65( \pm 3.134)$ & $21.07( \pm 3.819)$ & $\mathrm{P}=0.0001$ \\
\hline 3 & $\begin{array}{l}\text { Mean tricep skin fold } \\
\text { thickness }(\mathrm{mm})\end{array}$ & $20.46( \pm 3.534)$ & $15.80( \pm 3.261)$ & $\mathrm{P}=0.0001$ \\
\hline 4 & Mean disease duration (wk) & $223.94( \pm 197.416)$ & $64.78( \pm 73.567)$ & 0.0001 \\
\hline 5 & Presence of Lupus nephritis & 31 out of 35 patients & 46 out 69 patients & $\begin{array}{c}\text { Pearson } x^{2} \text { test } \\
x^{2}=11.94 \\
\mathrm{P}=0.036\end{array}$ \\
\hline 6 & SLICC/ACR Damage Index & $0.629( \pm 0.77)$ & $0.319( \pm 0.63)$ & $\mathrm{P}=0.0304$ \\
\hline 7 & Anti-DsDNA Positivity & 10 out of 35 patients & 27 out 69 patients & $\begin{array}{l}x^{2}=5.182 \\
p=0.02282\end{array}$ \\
\hline 8 & $\begin{array}{l}\mathrm{C}_{3} \text { level } \\
\text { (Number of patients) }\end{array}$ & $\begin{array}{c}\text { Low- } 9 \\
\text { Normal- } 26\end{array}$ & $\begin{array}{c}\text { Low - } 35 \\
\text { Normal - } 34\end{array}$ & $\begin{array}{l}x^{2}=5.951 \\
\mathrm{P}=0.01471\end{array}$ \\
\hline 9 & ESR & $42.11( \pm 21.41)$ & $52.27( \pm 22.24)$ & $\mathrm{P}=0.03$ \\
\hline 10 & Sr. Creatine $(\mathrm{mg} / \mathrm{dl})$ & $1.048( \pm 0.338)$ & $0.9217( \pm 0.28)$ & $\mathrm{P}=0.047$ \\
\hline 11 & $\begin{array}{l}\text { Mean cumulative dose }(\mathrm{Gm}) \\
\text { i) Pulse MPS } \\
\text { ii) oral prednisolone } \\
\text { iii) } \\
\end{array}$ & $\begin{array}{c}3.44( \pm 1.307) \\
15.818( \pm 10.877) \\
11.50( \pm 5.171) \\
\end{array}$ & $\begin{array}{c}2.92( \pm 0.335) \\
6.245( \pm 4.067) \\
7.28( \pm 4.452) \\
\end{array}$ & $\begin{array}{c}\mathrm{P} \text { value } \\
0.005 \\
<0.0001 \\
0.001 \\
\end{array}$ \\
\hline 12 & $\begin{array}{l}\text { Mean Carotid intima-media } \\
\text { thickness }(\mathrm{cm})\end{array}$ & $0.050( \pm 0.008)$ & $0.040( \pm 0.005)$ & 0.0001 \\
\hline
\end{tabular}

MetS was significantly associated with higher age, high BMI, longer disease duration, presence of lupus nephritis, positive anti-ds DNA \& Anti-ds DNA and higher cumulative steroid usage.

\section{Discussion}

Out of 104 patients studied, $33.7 \%$ were found to have metabolic syndrome (MetS) as per AHA/NHLBI modified NCEP/ATP III criteria. Similar studies done previously have reported the prevalence to be from $16-38.2 \%$ [13-16,21]. The mean age of SLE patient with MetS was $32.86 \pm 9.34$ years where as that of SLE without $27.26 \pm 9.78$ ( $\mathrm{P}=0.006)$. Among demographic parameters higher age factors was a risk factor for MetS. This is in concordance with SLICC-RAS inception cohort study where mean age of patient with MetS was $36.9 \pm 13.3$ years \& that of patient without MetS $34.9 \pm 14.7$ years. The presence of MetS was seen to be more with increasing age.

Metabolic syndrome score of SLE patient- Among the patients with MetS ( $\mathrm{n}=35), 17$ had presence of 3 components of MetS, 12 had 4 components whereas 6 had all components of MetS. Among the patients without MetS (n=69), 34 patients had 2 components, 27 had one component while only 8 patients did not have any component of MetS. So the scores of either 2 or 1 are at risk of developing metabolic syndrome. Negron et al found MetS score $2 \& 1$ in 19.6 \& 26 $\%$ of study population respectively which is lower than our study results [14]. Similarly Butlink et al found MetS score of $2 \& 1$ in $27.7 \& 31.2 \%$ population [13]. 


\section{Original Research Article}

Distribution of individual components of the metabolic syndrome- Out of the 104 patients in the present study, 30\% had high blood pressure, $26 \%$ had impaired fasting glucose or were on treatment for diabetes mellitus, $37 \%$ had decreased level of HDL-cholesterol or were on therapy for decreased HDL-cholesterol, $82 \%$ had either high serum triglycerides or were taking treatment of for high triglycerides and $42 \%$ had increased waist circumference. Hypertriglyceridemia was much more common $(82 \%)$ in the patients included in the present study when compared to other studies. Also patients with MetS in the present study had significantly higher body mass index $(\mathrm{p}=0.0001)$ when compared to those without MetS.

\section{Comparison of distribution of various components of MetS in SLE patients}

\begin{tabular}{|l|c|c|c|c|}
\hline $\begin{array}{l}\text { Components of Metabolic Syndrome } \\
\text { in SLE Patients }\end{array}$ & $\begin{array}{c}\text { Present study } \\
(\mathbf{n = 1 0 4})\end{array}$ & $\begin{array}{c}\text { Chung et al } \\
{[\mathbf{1 6}](\mathbf{n}=\mathbf{1 0 2})}\end{array}$ & $\begin{array}{c}\text { Butlink et al } \\
{[\mathbf{1 3}](\mathbf{n}=\mathbf{1 4 1})}\end{array}$ & $\begin{array}{c}\text { Parker et al } \\
{[\mathbf{2 1}](\mathbf{n}=\mathbf{1 4 9 4}}\end{array}$ \\
\hline $\begin{array}{l}\text { High Blood Pressure or Therapy of } \\
\text { HTN }\end{array}$ & $30 \%$ & $51 \%$ & $60 \%$ & $48 \%$ \\
\hline $\begin{array}{l}\text { Impared Fasting Glucose or Therapy } \\
\text { for DM }\end{array}$ & $26 \%$ & $2.9 \%$ & $11 \%$ & $20.2 \%$ \\
\hline $\begin{array}{l}\text { Decreased HDL-Cholesterol Or } \\
\text { Therapy }\end{array}$ & $37 \%$ & $52 \%$ & $32 \%$ & $59.1 \%$ \\
\hline Increased Triglyceride Or Therapy & $82 \%$ & $27.5 \%$ & $23 \%$ & $46.1 \%$ \\
\hline Increased Waist Circumference & $42 \%$ & $48 \%$ & $\begin{array}{c}\text { No Data } \\
\text { available }\end{array}$ & $48.4 \%$ \\
\hline
\end{tabular}

Disease duration- The mean disease duration since the time of diagnosis in patients with MetS in present study was 223.9 \pm 197.4 weeks whereas it was $64.7 \pm 73.6$ in the patients. Hence patient with MetS had a longer disease than those without MetS ( $\mathrm{p}=0.0001$ ). This is in concordance with the study by Negron et al where patients with MetS had longer disease duration than those without MetS $(11.2 \pm 8.3$ years vs $7.2 \pm 2.9$ years, $p=0.0001)$ [14].

Renal involvement- 31 out of 35 patients with MetS had evidence of renal involvement, of which 30 had Lupus Nephritis Class III or above. Amongst those without MetS 46 had evidence of renal involvement, of which 37 had Lupus Nephritis Class III or above. The presence of MetS correlated with the presence of renal involvement as determined by Pearson Chi-square test $(\mathrm{p}=0.036)$. In the Systemic Lupus International Collaborating Clinic Registry for Atherosclerosis (SLICC-RAS) inception cohort, active renal involvement is associated with presence of MetS.

Disease activity- The mean SLEDAI score in patient score in patients with MetS was 3.43 \pm 5.0 while that with patients without MetS was $5.33 \pm 6.86(\mathrm{p}=0.142)$. No significant association was noted between disease activity \& presence of MetS in the present study. However in the SLICC-RAS inception cohort, a significant association was noted between disease activity \& presence of MetS. The mean SLEDAI-2K SCORE in patients with MetS in the SLICC-RAS inception cohort was $6.79 \pm 6.19$ while the among those without MetS was $5.24 \pm 5.25(\mathrm{P}=<0.001)$ [21]. This could be explained on the basis that the patients in the SLICC-RAS cohort had shorter disease duration compared to patients in our study. Negron et al [14] had also found significant association between disease activity and presence of metabolic syndrome; however disease activity was measured using SLAM-R scores in their study. Patients with MetS had higher mean SLAM-R scores $(5.7 \pm 3.0$ vs $4.6 \pm 2.6, \mathrm{p}=0.020)$

Damage Index: The mean SLICC/ACR Damage index in patients with MetS in the present study was $0.63 \pm 0.77$ while in those without MetS was $0.32 \pm 0.63, \mathrm{p}=0.0304$. Patients with MetS had higher damage index than those without MetS. Similar association was found by Negron et al with mean DI scores of $1.1 \pm 1.2$ in patients with MetS vs $0.7 \pm 1.2$ in patients without $\operatorname{Met} S(\mathrm{p}=0.023)$ [14].

\section{Serological Parameters}

i) ANA \& Anti-dsDNA: At the study visit, 27 out of 35 patients with MetS had positive ANA whereas 64 out of the 69 patients without MetS had positive ANA. 10 patients out of 35 patients with MetS had positive for Anti-dsDNA whereas 64 out of the 69 patients without
MetS. Of these 2 antibodies, significant association was seen between Anti-dsDNA \& presence of MetS, which is similar to associations noted in the SLICC-RAS inception cohort [21]. 


\section{Original Research Article}

ii) Complement level: In the present study, patients without MetS had lower C3 levels compared to those with metabolic syndrome $(p=0.01417)$. This also correlated with the finding that patients without metabolic syndrome had higher disease activity in our study. However no significant difference was noted between the two groups with respect to low $\mathrm{C} 4$ levels $(\mathrm{p}=0.4155)$

iii) Anti-cardiolipin antibody: In the present study, 13 out of 35 patients had positive titres for anti-cardiolipin antibody (IgG or IgM or both) , whereas 24 out of 69 patients without MetS had anti-cardiolipin antibodies. No significant association was noted between the presence anti-cardiolipin antibodies \& presence of MetS in our study $(\mathrm{p}=0.81)$.

iv) Erythrocyte Sedimentation Rate (ESR): The mean ESR was higher in patients without MetS (52.27 \pm 22.24$)$ than in those with MetS $(42.11 \pm 21.41)$. Patients without MetS had more active inflammation as suggested by high ESR when compared to those with $\operatorname{Met} S(p=0.03)$. This also correlates with higher disease activity and low C3 in patients without MetS. However in the study by Negron et al patients with MetS had higher ESR when compared to those without MetS [14].

v) C Reactive Protein: Among the patients with MetS in the present study $(n=35), 19$ had high CRP levels at the study visit while 42 patients without MetS $(n=69)$ had high CRP levels. No association was found between CRP reactivity \& Presence of MetS ( $p=0.5194)$. However, Chung et al had found higher CRP levels in the subset of SLE patients with MetS in their study $(\mathrm{p}=0.0001)[16]$.

vi) Serum Creatine: In the present study, association was seen in between the presence of high creatine \& MetS ( $p=0.0047)$, similar to studies done by But link et $\mathrm{al}(\mathrm{p}=0.045)$ and Chung et al $(\mathrm{p}=0.04)[13,16]$.

vii) Serum uric acid: The mean uric acid level in patients with MetS in the present study was $5.67 \pm 1.516$ $\mathrm{mg} \%$. No association was noted between serum uric acid levels and the presence of MetS ( $\mathrm{p}=0.656)$.

\section{Treatment Parameters}

i) Steroids: Out of 35 patients with MetS, 34 had received intravenous pulse methylprednisolone therapy in the past, whereas 58 out of 69 patients without MetS had received intravenous pulse methylprednisolone therapy. The cumulative dose of methylprednisolone was higher in patients with MetS than those without
MetS ( $\mathrm{p}=0.005)$. All the patients in the present study had received oral glucocorticoids. The mean cumulative dose of oral prednisolone was higher in patients with MetS $(15.818 \pm 10.877)$ than those without without MetS (6.245 $\pm 4.067, \mathrm{p}<0.0001)$. Most studies have found significant association between current \& cumulative steroid use and the presence of metabolic syndrome [13$16,21]$.

ii) Cyclophosphomide: Out of the 35 patients with MetS \& 69 patients without MetS, 30 patients in each group had received cyclophosphomide therapy. Though the cyclophosphomide usage is higher in group with MetS, this is confounded by the fact that patients with MetS had more renal involvement and longer duration of disease. iii) Mycophenolate mofetil, Azathioprine and Methotrexate: Only 12 patients in our study had received had received mycophenolate mofetil as an immunosuppressive agent. Of them 2 had MetS. As the number of patients who had received mycophenolate mofetil was less in the present study, correlation between use of mycophenolate mofetil \& MetS could not be analysed, same with patients receiving Azathioprine $(n=11)$ or Methotrexate $(n=4)$ and hence reasonable comparison could not made. Larger studies are needed to study effect of Mycophenolate mofetil, Azathioprine and Methotrexate on MetS phenotype in SLE patients.

Carotid intimal thickness: In the present study, the mean value of carotid intima-media thickness was higher in patients with MetS $(0.050 \pm 0.008 \mathrm{~cm})$ than those without MetS $(0.040 \pm 0.005) \quad(\mathrm{p}=0.0001)$. Considering carotid intima-media thickness to be one of the predictors of subclinical atherosclerosis, patients with MetS are more prone to develop subclinical atherosclerosis than those without MetS [22].

\section{Conclusion}

Out of enrolled 104 patients with systemic lupus erythmatosus, $33.7 \%$ patients $(n=35)$ had metabolic syndrome as per AHA/NHLBI modified NCEP/ATP III criteria. Among demographic parameters increasing age factors was a risk factor for MetS. Hypertriglyceridemia was the the most common component of MetS, seen in $82 \%(n=85) \&$ increased waist circumference in $42 \%$ of the patient. Higher BMI, higher triceps skin fold thickness, longer disease duration, the presence of lupus nephritis were associated with presence of metabolic syndrome in SLE patients. However, no correlation was found between disease activity (as measured by SLEDAI-2K), neuropsychiatric involvement and presence of MetS. Among serological parameters, a 
positive anti-ds DNA and higher serum creatinine were associated with the presence of MetS; where as low C3 \& high ESR were more frequent in those without MetS. However, there was no association was found between ANA, Low $\mathrm{C}_{3}$, Anti-cardiolipin antibody, CRP levels \& serum uric acid levels and presence of MetS. Patient with MetS had higher damage index due to lupus disease as measured by SLICC/ACR damage index as compared to those without MetS. Higher cumulative dose of steroids (both intravenous pulse\& oral prednisolone) was associated with MetS.

Though cyclophosphomide usage was higher in group with MetS, this is confounded by the fact that patients with MetS had more renal involvement \& longer duration of disease. As only few patient had received mycofenolate mofetil, azathioprine and methotrexate, comparisons could not be made.

Patient with MetS had higher carotid artery intimamedia thickness than those without MetS. In conclusion, higher age, longer disease duration, lupus nephritis, positive anti-ds DNA and higher cumulative steroid usage were associated with MetS in our study which in turn was associated with increased carotid intima-media thickness.

Thus screening of SLE patients for metabolic syndrome will help in identifying those at risk for premature atherosclerotic cardiovascular disease, so that early lifestyle and therapeutic interventions can be initiated.

Contributors: All authors contributed to data collection, analysis and manuscript preparation \& have critically reviewed and edited the manuscript, and approved its publication.

What this study add to existing knowledge? There has been a 4-fold rise of Coronary Heart Disease prevalence in India during the past 40 years, can be explained by the alarming rise in the prevalence of coronary risk factors like diabetes, hypertension, atherogenic dyslipidemia, smoking, central obesity and physical inactivity. In addition to that SLE will increase the risk further particularly in young population.

Very few studies address this association between MetS in SLE in Indian population. So, Screening for risk factors of MetS in Indian SLE patients will definitely help in identifying the risk for premature atherosclerotic cardiovascular disease for early intervention.

Funding: Nil, Conflict of interest: None

Permission of IRB: Yes

\section{References}

1.Dall'era M, Wofsy D. Clinical features of Systemic Lupus Erythematosus. Kelly's Book of Rheumatology . $9^{\text {th }}$ Edition, Philadelphia. Saunders Elsevier; 2012, P 1283-1303. eBook ISBN: 978 1455737673.

2. Urowitz MB, Bookman AA, Koehler BE, et al. The bimodal mortality pattern of systemic lupus erythematosus. Am J Med. 1976 Feb;60(2):221-5.

3.Gladman DD, Urowitz MB. Morbidity in systemic lupus erythematosus. J Rheumatol Suppl. 1987 Jun;14 Suppl 13:223-6.

4. Petri M, Perez-Gutthann S, Spence D, et al. Risk factors for coronary artery disease in patients with systemic lupus erythematosus. Am J Med. 1992 Nov; 93 (5):513-9.

5. Doria A, Iaccarino L, Sarzi-Puttini P, et al. Cardiac involvement in systemic lupus erythematosus. Lupus. 2005;14(9):683-6. DOI:10. 1191/ 0961203305lu2200oa

6. Manzi S, Meilahn EN, Rairie JE, et al. Agespecific incidence rates of myocardial infarction and angina in women with systemic lupus erythematosus: comparison with the Framingham Study.AmJEpidemiol. 1997Mar1;145(5): 408-15

7. Petri MA, Kiani AN, Post W, et al. Lupus Atherosclerosis Prevention Study (LAPS). Ann Rheum Dis. 2011 May;70(5):760-5. doi: 10.1136/ ard.2010.136762. Epub 2010 Dec 21.

8. Ahmad Y, Shelmerdine J, Bodill $\mathrm{H}$, et al. Subclinical atherosclerosis in systemic lupus erythematosus (SLE): the relative contribution of classic risk factors and the lupus phenotype. Rheumatology (Oxford). 2007 Jun;46(6):983-8. Epub 2007 Mar 23.

9. Roman MJ, Shankar BA \& et al. Prevalence and correlates of accelerated atherosclerosis in Systemic Lupus Erythematosus. N Engl J Med. 2003 Dec 18; 349 (25): 2399-406. doi:10.1056/ NEJM oa035471.

10. El-Magadmi, Bodill H \& et al. Systemic Lupus Erythematosus: an independent risk factor for endothelial dysfunction in women. Circulation. 2004 Jul 27;110(4):399-404. Epub 2004 Jul 19. doi:10.1161/01.CIR.0000136807.78534.50. 


\section{Original Research Article}

11. Reilly MP, Rader DJ. The metabolic syndrome: more than the sum of its parts? Circulation. 2003 Sep 30;108(13):1546-51. DOI:10.1161/01.CIR. 0000088 846.10655.E0

12. Parker B, Bruce IN. The Metabolic Syndrome in Systemic Lupus Erythematosus. Rheumatic Dis Clin North Am. 2010 Feb; 36 (1): 81-97, viii. doi: 10.1016/j.rdc. 2009.12.004.

13. Bultink IE, Turkstra F, Diamant $M$, et al. Prevalence of and risk factors for the metabolic syndrome in women with systemic lupus erythematosus. Clin Exp Rheumatol. 2008 Jan-Feb;26 (1): 32-8.

14. Negron AM, Molina MJ \& et al. Factors associated with metabolic syndrome in patients with metabolic syndrome in patients with Systemic Lupus Erythematosus from Puerto Rico. Lupus. 2008 Apr; 17(4):348-54. doi: 10.1177/096120330 7086645.

15. Sabio JM, Zamora-Pasadas M, Jiménez-Jáimez $\mathrm{J}$, et al. Metabolic syndrome in patients with systemic lupus erythematosus from Southern Spain. Lupus. 2008 Sep; 17(9): 849-59. doi: 10.1177/ 0961203308093554.

16. Chung CP, Avalos I, Oeser A, et al. High prevalence of the metabolic syndrome in patients with systemic lupus erythematosus: association with disease characteristics and cardiovascular risk factors. Ann Rheum Dis. 2007 Feb;66(2):208-14. Epub 2006 Aug 10.
17. Simrad JF, Costenbader KH. Epidemiology \& Classification of Systemic Lupus Erythematosus. In: Hochberg MC, Silman AJ, Smolen JS, Weinblatt ME, Welsman MH, editors. Rheumatology. $5^{\text {th }}$ Edition . Philadelphia. Mosby Elsevier; 2011, p 1301-1306.

18. Gladman DD, Ibañez D, Urowitz MB. Systemic lupus erythematosus disease activity index 2000. J Rheumatol. 2002 Feb;29(2):288-91.

19. Gladman DD, Urowitz MB \& et al. The relitability of Systemic lupus International Collabrating Clinic/ American College of rheumatology Damage Index in patients with Systemic Lupus Erythematosus. Arthritis Rheum. 1997; 40: 809-13. DOI:10.1002/1529-0131 (199705) 40:5\&lt;809::AID-ART5\&gt;3.0.CO;2-X.

20. Grundy SM, Cleeman JI, Daniels SR, et al. Diagnosis and management of the metabolic syndrome: an American Heart Association/National Heart, Lung, and Blood Institute Scientific Statement. Circulation. 2005 Oct 25;112(17):2735-52. Epub 2005 Sep 12. DOI: 10.1161/CIRCULATIONAHA.105.169404

21. Parker B, Urowitz MB \& et al. Clinical association of Metabolic Syndrome in systemic lupus Erythematosus: Data from the international inception cohort. Ann Rheum Dis 2013; 72:130814 doi: 10.1136/annrheumdis-2012-202106. Epub 2012 Sep 3.

22. Cobble M, Bale B. Carotid intima-media thickness: knowledge and application to everyday practice. Postgrad Med. 2010 Jan;122(1):10-8. doi: 10.3810/pgm.2010.01.2091.

\section{How to cite this article?}

Rajadhyaksha A.G, Sarate N, Mangalgi S. A comparative study of clinical profile \& investigative parameters of systemic lupus erythematosus patients with \& without metabolic syndrome. Int J Med Res Rev 2018;6(08):444-451. doi:10.17511/ijmrr.2018.i08.08. 